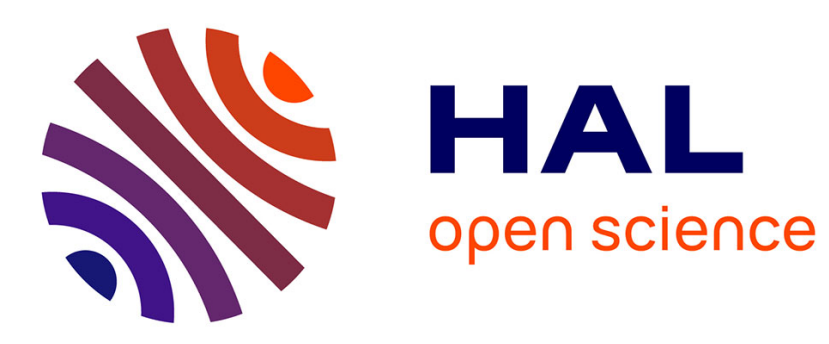

\title{
Purification of homogeneous forms of fungal peroxygenase
}

René Ullrich, Christiane Liers, Sylvia Schimpke, Martin Hofrichter

\section{To cite this version:}

René Ullrich, Christiane Liers, Sylvia Schimpke, Martin Hofrichter. Purification of homogeneous forms of fungal peroxygenase. Biotechnology Journal, 2009, 4 (11), pp.1619. 10.1002/biot.200900076 . hal00498913

\section{HAL Id: hal-00498913 https://hal.science/hal-00498913}

Submitted on 9 Jul 2010

HAL is a multi-disciplinary open access archive for the deposit and dissemination of scientific research documents, whether they are published or not. The documents may come from teaching and research institutions in France or abroad, or from public or private research centers.
L'archive ouverte pluridisciplinaire HAL, est destinée au dépôt et à la diffusion de documents scientifiques de niveau recherche, publiés ou non, émanant des établissements d'enseignement et de recherche français ou étrangers, des laboratoires publics ou privés. 


\section{Purification of homogeneous forms of fungal peroxygenase}

\begin{tabular}{|c|c|}
\hline Journal: & Biotechnology Journal \\
\hline Manuscript ID: & biot.200900076.R2 \\
\hline Wiley - Manuscript type: & Technical Report \\
\hline $\begin{array}{r}\text { Date Submitted by the } \\
\text { Author: }\end{array}$ & 02-Jun-2009 \\
\hline Complete List of Authors: & $\begin{array}{l}\text { Ullrich, René; International Graduate School Zittau, Environmental } \\
\text { Biotechnology } \\
\text { Liers, Christiane; International Graduate School Zittau, } \\
\text { Environmental Biotechnology } \\
\text { Schimpke, Sylvia; University of Technology Dresden, Biotechnology } \\
\text { Center and Center for Regenerative Therapies } \\
\text { Hofrichter, Martin; International Graduate School Zittau, } \\
\text { Environmental Biotechnology }\end{array}$ \\
\hline \multicolumn{2}{|l|}{ Main Keywords: } \\
\hline \multicolumn{2}{|l|}{ All Keywords: } \\
\hline Keywords: & protein purification, isoform, peroxygenases \\
\hline
\end{tabular}

\section{S ScholaroNE" \\ Manuscript Central}




\section{Technical Report}

\section{Purification of homogeneous forms of fungal peroxygenase}

René Ullrich ${ }^{1}$, Christiane Liers ${ }^{1}$, Sylvia Schimpke ${ }^{2}$ and Martin Hofrichter ${ }^{1}$

${ }^{1}$ Unit of Environmental Biotechnology, International Graduate School of Zittau,

Zittau, Germany

${ }^{2}$ Biotechnology Center and Center for Regenerative Therapies, University of Technology Dresden, Dresden, Germany

Correspondence: René Ullrich, Unit of Environmental Biotechnology, International Graduate School of Zittau, Markt 23, 02763 Zittau, Germany

E-mail: ullrich@ihi-zittau.de

Fax: $+49-3583-612734$

Keywords: Agrocybe aegerita / Isoform / Peroxygenases / Protein purification Abbreviations: AaP, Agrocybe aegerita peroxygenase; FPLC, fast protein liquid chromatography; IEF, preparative isoelectric focusing

Extracellular peroxygenase from the agaric fungus Agrocybe aegerita is a versatile biocatalyst that oxygenates various substrates by means of hydrogen peroxide. The enzyme is routinely produced in suspensions of soybean meal and has until now been purified by several steps of fast protein liquid chromatography (FPLC) using different ion exchangers. The final protein fraction had a molecular mass of $46 \mathrm{kDa}$ but still consisted of several incompletely separated proteins with slightly differing isoelectric points $(p / 5.2,5.6,6.1)$, probably representing differently glycosylated isoforms. This made it difficult to further purify the individual protein forms. Since homogeneous protein fractions are a pre-requisite for $\mathrm{X}$-ray crystallography and specific structure-function studies, an appropriate FPLC procedure was developed starting with pre-purification of crude peroxygenase on SP Sepharose followed by chromatofocusing on a Mono $\mathrm{P}$ column and elution with a $\mathrm{pH}$ gradient. Three sufficiently separated main protein peaks were eluted from the Mono P column and confirmed to be distinct forms of aromatic peroxygenase with different $\mathrm{p} / \mathrm{s}$. All $A$. 
aegerita peroxygenase forms oxygenated toluene and naphthalene and no catalytic differences were observed between them. We tested also two devices for preparative isoelectric focusing (Rotofor, IsoPrime systems) for peroxygenase separation but resolution and protein recovery were not sufficient.

\section{Introduction}

The agaric mushroom Agrocybe aegerita produces a secretory heme-thiolate protein $(A$. aegerita peroxygenase, AaP) that can be regarded as a functional hybrid of peroxidases and cytochrome P450 monooxygenases [1-3], The enzyme is able to oxygenate (epoxidize, hydroxylate), brominate and oxidize a wide range of aromatic and aliphatic substrates and hence may be one of the most versatile oxidoreductases known so far [4-6]. The fungus secrets considerable amounts of this peroxygenase particularly in soybean meal suspension [1]. However, the purification of $\mathrm{AaP}$ is laborious and requires several steps of ultrafiltration and fast protein liquid chromatography (FPLC) using different ion exchangers to get rid of the soy proteins and peptides. The final enzyme fractions obtained show one mass band (46 kDa) on SDS-PAGE, but still consist of two to six different proteins (three major forms along with a varying number of minor ones) with $\mathrm{p} / \mathrm{s}$ between 4.9 and 5.7 (differences in p/0.1-0.8) [1]. However, specific analyses such as X-ray diffraction studies or comparative kinetic studies require the preparation of homogeneous protein fractions, i.e., the three major AaP forms must be purified to homogeneity [7].

The use of high-resolution Mono Bead resins in ion exchange chromatography (e.g., Mono $\mathrm{Q}$, Mono S) is a well established and has been successfully applied for the purification of protein isoforms and isoenzymes [8-10]. The application of FPLC using a $\mathrm{pH}$ gradient, the so-called chromatofocusing, has been successfully used for 
separating antibodies and their fragments, as well as peptides and oligonucleotides. However, there are only a few articles describing the purification of extracellular fungal enzymes by chromatofocusing [11-15].

Preparative isoelectric focusing (IEF) in buffered liquids is another established method for purifying similar protein forms and is usually performed using a multicompartment electrolyzer or a Rotofor cell device [16-20]. Both methods are tricky and time consuming, and have been applied mainly for the purification of peptides, protein fragments and small proteins, polynucleotides or intracellular bacterial enzymes [20-23]. Reports on the separation and fractionation of different forms of fungal secretory proteins by these preparative IEF devices are rarely found in the literature [18].

In the present work, we studied the separation of different peroxygenase proteins (AaP isoforms) by preparative IEF and chromatofocusing using $\mathrm{pH}$ gradients with the aim of obtaining homogeneous protein fractions for further comparative studies. Both methods are known to be sensitive to slightly varying surface charges of proteins, and hence may be the methods of choice for the successful separation of quite similar peroxygenase molecules.

\section{Materials and methods}

\subsection{Enzyme assay and chemicals}

Activity of peroxygenase was determined in $1-\mathrm{mL}$ cuvettes by following the oxidation of veratryl alcohol into veratraldehyde $\left(\varepsilon_{310}=9.3 \mathrm{mM}^{-1} \mathrm{~cm}^{-1}\right)$ in $50 \mathrm{mM}$ sodium citrate-phosphate buffer at $\mathrm{pH} 7$ [1]. All chemicals used were of the highest purity available and were obtained from Sigma-Aldrich (Weinheim, Germany) and Merck (Darmstadt, Germany). 


\subsection{Preparation of protein crude extract}

All purification experiments were started from crude AaP produced by the Black poplar mushroom, $A$. aegerita strain TM A1 (strain deposited at DSMZ no. 22459). Production was carried out in a 5-L stirred-tank bioreactors (Biostat B, Braun Biotech International $\mathrm{GmbH}$, Melsungen, Germany) containing a complex liquid medium based on soybean meal [1]. Culture liquid (4 L) was harvested just after the activity had reached its maximum level (about $1500 \mathrm{U} / \mathrm{L}$ ). The fungal mycelium was removed by filtration (filter GF6; Schleicher \& Schuell, Dassel, Germany) and the enzyme-containing liquid was concentrated 60 -fold by two steps of ultrafiltration using a tangential-flow cassette system (Omega Minisette ${ }^{\mathrm{TM}}$, cut-off $10 \mathrm{kDa}$, Pall Corporation Hauppauge, NY, USA) and a 150-mL stirred cell system (10 kDa cut-off polysulphone membrane, Pall Life Sciences, Dreieich, Germany).

\subsection{Protein purification by ion exchange chromatography}

For subsequent protein separation, the crude AaP was pre-purified by FPLC using an ÄKTA system (GE HealthCare Europe GmbH, Freiburg, Germany) fitted with the strong cation exchanger SP Sepharose FF (column XK 26/20, GE HealthCare).

Proteins were eluted with a linear gradient of $0-0.6 \mathrm{M} \mathrm{NaCl}$ in $10 \mathrm{mM}$ sodium acetate buffer $(\mathrm{pH} 4.75)$ at a flow rate of $13 \mathrm{~mL} / \mathrm{min}^{-1}$ (modified according to [1]). AaP-containing fractions were pooled, concentrated and dialyzed against $10 \mathrm{mM}$ sodium acetate $(\mathrm{pH} 5.0 ; 10 \mathrm{kDa}$ cut-off polysulphone membrane, Pall Life Sciences). This pre-purified AaP fraction was afterwards used for all further separation studies.

In a first approach, we attempted to separate the AaP proteins by ion exchange on Mono Bead ${ }^{\mathrm{TM}}$ columns using either strong cation (Mono S, $5 \mathrm{~mm} \times 50 \mathrm{~mm}$, $\mathrm{pH} 4.5$ ) 
or strong anion (Mono Q, $5 \mathrm{~mm} \times 50 \mathrm{~mm}, \mathrm{pH}$ 7.0) exchangers. Separations were carried out with sodium acetate $(10 \mathrm{mM})$ as solvent and an increasing concentration of $\mathrm{NaCl}(0-0.3 \mathrm{M})$ for elution.

\subsection{Protein purification by preparative IEF}

IEF separation was done with an IsoPrime multi-chambered electrofocusing unit (Hoefer Scientific Instruments, San Francisco, CA, USA). The purification module consisted of eight chambers separated by seven isoelectric membranes of predetermined $\mathrm{pH}$. The polyacrylamide (5\%) membranes were reinforced by glass fiber filters (GF53, Schleicher \& Schuell) and contained covalently bound acrylamido buffers ( $p /$ select, Fluka Chemie $\mathrm{GmbH}$, Buchs, Switzerland), which imparted a definite $\mathrm{pK}_{\mathrm{a}}$ value to each membrane. Membrane preparation was performed according to the manufacturer's instructions using the software program Doctor-pH (Hoefer Scientific Instruments) that determined the required concentration of the acrylamido buffers for adjusting the desired $\mathrm{pH}$. Seven slightly differing $\mathrm{pH}$ values $(5.00,5.37,5.53,5.65,5.73,5.85,6.00)$ were chosen, covering the whole $p /$ range of possible AaP forms (previously determined by analytical IEF [1]). After assembling the membranes, a pre-run was carried out at $11^{\circ} \mathrm{C}$ and $4 \mathrm{~W}$ constant power supply ( $3000 \mathrm{~V}, 20-25 \mathrm{~mA}, 3.5 \mathrm{~mL} / \mathrm{min}$ ) with deionized water to establish the $\mathrm{pH}$ gradient within the membranes. After removing the pre-run water, the protein sample was placed into the central chamber. The outer chambers were filled with the corresponding electrolytes. The anode buffer was $5 \mathrm{mM}$ acetic acid and the catholyte was $5 \mathrm{mM}$ histidine. Separation runs were done in the constant power mode $(4 \mathrm{~W})$ resulting in currents up to $25 \mathrm{~mA}$ with a flow rate of $2.5 \mathrm{~mL} / \mathrm{min}$. To improve protein separation and recovery, running conditions were varied in following 
ranges: phase $1(0.5-2 \mathrm{~h}, 650-800 \mathrm{~V})$, phase $2(1-1.5 \mathrm{~h}, 1000-1500 \mathrm{~V})$, phase 3 (0.5-25 h, 1500-3000 V).

Further separation experiments by preparative IEF were carried out with a Rotofor unit (Bio-Rad, Hercules, CA, USA). The enzyme solution was mixed with ampholytes ( $\mathrm{pH} 4-7$, Fluka Chemie), which then generated a linear $\mathrm{pH}$ gradient in the electrical field of the focusing chamber. A pre-run of the system was performed ( $5 \mathrm{~min}, 5 \mathrm{~W}$ ) with deionized water prior to loading the protein sample. After injection of the enzyme solution through the inlet of the sample chamber, the run was performed at a constant power of $4 \mathrm{~W}$ and $450 \mathrm{~V}$ for $4 \mathrm{~h}$. To achieve sufficient separation, the concentration of electrolyte buffers $(500 \mathrm{mM}$ acetic acid $\mathrm{pH} 2.2$; $100 \mathrm{mM}$ histidine $\mathrm{pH}$ 7.6; $500 \mathrm{mM}$ propionic acid $\mathrm{pH}$ 2.6; $100 \mathrm{mM}$ histidine $\mathrm{pH}$ 7.6) and of ampholytes (2-4\%) was varied. Finally the protein fractions were collected by applying a vacuum to the separation chamber. All active fractions were later analyzed by analytical IEF.

\subsection{Protein purification by chromatofocusing}

This method was also accomplished using the ÄKTA-FPLC system mentioned above but applying a pH instead of a salt gradient. SP Sepharose-pre-purified protein was separated on a chromatofocusing column containing the mixed anion exchanger Mono P (5 mm × $200 \mathrm{~mm}$, GE HealthCare). The column was preequilibrated with $25 \mathrm{mM}$ Bis-Tris- $\mathrm{HCl}$ buffer $(\mathrm{pH} 7)$ and the protein solution loaded onto the column by a sample pump (GE Healthcare Europe). The bound AaP protein was eluted with a $\mathrm{pH}$ gradient established by $10 \%$ Polybuffer $74(\mathrm{pH} 4.0$, GE HealthCare) at a flow rate of $1 \mathrm{~mL} / \mathrm{min}$. Active fractions were collected with an auto-sampler, pooled and analyzed by analytical IEF. 


\subsection{Analytical IEF and protein determination}

To determine the purity of protein and to evaluate the success of separation, the different protein fractions were electrophoretically analyzed using a Mini-Cell electrophoresis system (XCell Sure Lock ${ }^{\mathrm{TM}}$ Invitrogen, Karlsruhe, Germany) and Novex pre-cast IEF gels ( $\mathrm{pH} 3-7$, Invitrogen). Electrophoretical separation was carried out according to the manufacturer's protocol over $2.5 \mathrm{~h}$ at up to $6 \mathrm{~mA}$ (500 V limit). Protein bands were visualized with the Colloidal Blue Staining Kit from Invitrogen.

Protein concentration was determined by the method of Bradford using the $\operatorname{Rot}^{\Theta_{-}}$ Nanoquant Protein Assay Kit (Roth, Karlsruhe, Germany) with bovine serum albumin $\mathrm{H} 4$ (Roth) as the standard.

\subsection{Toluene and naphthalene oxidation by different AaP fractions}

The major AaP factions obtained after Mono P separation were compared with respect to their ability to oxygenate toluene and naphthalene [3]. Reactions were performed with $0.08 \mathrm{nmol}$ of each AaP fraction and $1000 \mu \mathrm{M}$ substrate in $1.5-\mathrm{mL}$ HPLC vials (total reaction volume $1 \mathrm{~mL}$ ) in potassium phosphate buffer (10 mM, pH 6.8) under continuous supply of $\mathrm{H}_{2} \mathrm{O}_{2}$ (KDS 100, KD Scientific, Holliston, MA, USA) at rates of $200 \mathrm{nmol} / \mathrm{min}$ over $10 \mathrm{~min}$ [6]. In the case of toluene, the reaction mixture contained in addition $5 \mathrm{mM}$ ascorbic acid to prevent further oxidation of cresols formed [4]. Reaction products were identified and quantified by HPLC and authentic standards as described previously [3].

\section{Results and discussion}


The different forms of peroxygenase from AaP secreted during the growth in soy bean media showed slightly differing $\mathrm{p} / \mathrm{s}$ and an almost identical molecular mass of $46 \mathrm{kDa}$ [1]. Since pure proteins are a fundamental pre-requisite for protein crystallography and comparative kinetic studies, we tested several high-resolution methods to obtain homogeneous AaP fractions.

\section{1 lon exchange chromatography}

The first chromatographic separation step was performed on the strong cation exchanger SP Sepharose FF and resulted in the removal of most yellowish-colored components of the soy bean medium (proteins/peptides and phenolics) [24, 25]. The elution profile showed one heme-related peak (420 nm), and fractions possessing a veratryl alcohol oxidizing activity (at $\mathrm{pH} 7)$, which consisted of three proteins with different $\mathrm{p} /$ (Figs. $1 \mathrm{~A}$ and $\mathrm{B}$ ). These latter fractions were collected.

$(($ Fig. 1))

The pre-purified and pooled enzyme fraction (Fig. 1) was used for further separation by ion exchange chromatography. The studies were focused on Mono Beads ${ }^{\mathrm{TM}}$ (Mono S, Mono Q), which are known to guarantee high resolution of protein separation [26]. However, the separation effect was not fully sufficient and just one active major fraction eluted from the Mono S column (Fig. 1C). In a previous study, two active enzyme fractions were obtained (designated as AaP I and II) by this purification step [1], and the major fraction (AaP II) has been used in most biochemical studies on AaP published so far [3-6]. The second ion chromatographic method was based on the strong anion exchanger Mono Q. Although the resolution was slightly better than that of the Mono S column, only two of the three main AaP forms were partly separated, and no p/-pure AaP protein was obtained (Fig. 1D). The overall insufficient purification of peroxygenases by ion exchange chromatography may be caused by similar surface charges of the proteins, which 
hampered their complete separation. Similar findings were reported for other fungal secretory proteins. Thus, two laccase isoforms of the well-investigated white-rot fungus Ceriporiopsis subvermispora could not be fully separated by ion exchange chromatography though their $\mathrm{p} /$ values differed to a greater extend than those of AaP. These laccase isoforms, and similarly an acidic manganese peroxidase form of the white-rot fungus Nematoloma frowardii b19 (nowadays referred to as Phlebia sp. Nfb19), were purified to homogeneity by preparative IEF $[18,27,28]$.

\subsection{Preparative IEF}

In consequence, our next attempt to separate the different AaP forms was the application of preparative IEF. Initially, a focusing technique using a multicompartment electrolyzer (IsoPrime, Hoefer, Amersham Pharmacia Biotech, Freiburg, Germany) was tested. However, almost the entire pre-purified protein bound irreversibly to the chamber membranes, which markedly swelled during the focusing process. This led to a high loss of AaP activity (up to 95\%), so that this technique could no use for separation of larger amounts of AaP. It has also been reported that the purification of a bacterial $\alpha$-amylase by a multi-compartment electrolyzer failed due to severe problems of protein precipitation near the $p /$ value of the enzyme [23]. In fact, reports describing a successful separation of proteins or peptides by the multi-compartment electrolyzer refer mostly to intracellular nonglycosylated proteins, oligopeptides or amino acids [29-31], and to our best knowledge, protocols concerning the isolation of extracellular fungal enzymes by this technique are lacking.

In most cases, the isolation of fungal proteins and their isoforms by IEF was done using thick IEF gels and a Multiphor II apparatus (Pharmacia, Sweden), which is no longer commercially available (personal communication, GE Healthcare) or by a Rotofor unit (Bio-Rad) $[8,17,18]$. Unfortunately, the latter procedure was also not 
suitable for fractionating the complex mixture of AaP proteins. The almost equal distribution of active enzyme fractions, without forming distinct activity maxima, and the accumulation of the AaP forms II and III (p/5.6 and 6.1) with increasing $\mathrm{pH}$ (fractions 8-12 - which becomes evident in the corresponding IEF gel) proved that no distinct AaP form can be obtained by this method (Figs. $2 A$ and $B$ ). Related findings were reported for peroxidase isoforms of the grape plant (Vitis vinifera) and for other heme proteins like horseradish peroxidase or lactoperoxidase [17, 23]. The low buffering capacity in the region around their $\mathrm{p} / \mathrm{s}$ was responsible for the equilibrium not being reached and for the failure of the focusing/separation process [32]. While the purification of single forms of fungal enzymes by preparative IEF has been described in a few reports [16, 33-35], the applicability of this procedure for the separation of chloroperoxidase or peroxygenases has not been demonstrated so far.

((Fig. 2))

\subsection{Chromatofocusing}

Since the separation methods sensitive to a low variation of the protein's surface charge seemed to be the only remaining possibility for the purification of the AaP forms, we tested chromatofocusing on a Mono $\mathrm{P}$ column in combination with a $\mathrm{pH}$ gradient elution. The AaP proteins eluted from the column one by one according to their $\mathrm{p} / \mathrm{s}$ with decreasing $\mathrm{pH}$ (from 7 to 4 ) of the mobile phase. Figure 3 shows the respective elution profile and reveals the separation of six veratryl alcohol oxidizing fractions (three major and three minor ones), corresponding to the earlier finding of six AaP forms with different p/s [1]. Thus, we finally obtained the three major AaP forms (AaP I-III) with a recovery of up to $79 \%$ overall, as well as specific activities of 77, 94 and $103 \mathrm{U} / \mathrm{mg}$ (Table 1). These three proteins formed single bands with $\mathrm{p} / \mathrm{s}$ 
of 5.2, 5.6 and 6.1 in the analytical IEF gel, proving the success of the purification procedure (Fig. 3B).

$(($ Fig. 3))((Table 1))

\subsection{Substrate oxidation by major AaP forms}

Toluene and naphthalene were used as substrates to prove the true peroxygenase nature of the AaP proteins obtained after Mono P separation. Results are summarized in Table 2 and show no significant differences between the different AaP forms, either in regard to the product pattern or to the percentage of individual oxidation products. All AaP fractions oxygenated toluene at both the side chain and the aromatic ring yielding benzyl alcohol, benzaldehyde and benzoic acid, and ocresol, $p$-cresol and methylhydroquinone, respectively. The ratio of side chain vs. aromatic hydroxylation was about $2: 1$ in all cases. Naphthalene was regioselectively converted into 1-naphthol and 2-naphthol at a ratio of 12:1. Differences in this ratio compared to an earlier study [3] can be explained by the use of a syringe pump for continuous peroxide supply instead of the repeated addition of $\mathrm{H}_{2} \mathrm{O}_{2}$. The findings suggest that the different AaP fractions represent quite similar enzyme proteins that may differ just in their glycosylation pattern [7]. Similar observations have already been made for the different isoforms of chloroperoxidase [36, 37].

((Table 2))

\section{Concluding remarks}

Our results suggest that preparative IEF techniques are unsuited to the separation of fungal peroxygenases with similar molecular mass and pl. On the other hand, we were able to demonstrate that pre-purification on SP Sepharose followed by 
chromatofocusing can be a powerful tool to attain this goal. To show that the separated AaP proteins are in fact differently glycosylated isoforms of one and the same protein (and do not represent different isoenzymes originating from different genes), future studies will focus on the determination of individual catalytic constants $\left(\mathrm{K}_{\mathrm{m}}\right.$ and $\left.\mathrm{k}_{\mathrm{cat}}\right)$ for the different peroxygenase forms and also follow specific molecular approaches to correlate AaP gene transcription and enzyme secretion (e.g., by realtime PCR). The separation method described here has already been successfully applied to prepare larger quantities of homogenous AaP forms. This was achieved by repeated injection of pre-purified protein and repeated running of the separation program until sufficient amounts of the three major proteins were collected (up to $5 \mathrm{mg}$ ). Meanwhile the purified proteins have successfully been crystallized and are currently being studied with respect to their crystal structure.

\author{
We thank Jörg Nüske (Friedrich Schiller University Jena), Martin Gunter Kluge \\ (Inge) and Katrin Scheibner for useful comments and Monika Brandt for technical \\ assistance. The work was supported by the European Union (integrated project \\ "Biorenew"), the Bundesministerium für Bildung, Wissenschaft und Forschung \\ (BMBF, project 0313433D) and the German Environmental Foundation (DBU, \\ project "Neuartige Peroxygenasen für die Produktion von Fein- und \\ Industriechemikalien"). \\ ((Funded by: \\ - European Union \\ - Bundesministerium für Bildung, Wissenschaft und Forschung \\ - German Environmental Foundation)) \\ The authors have declared no conflict of interest.
}

\title{
5 References
}


[1] Ullrich, R., Nuske, J., Scheibner, K., Spantzel, J. et al., Novel haloperoxidase from the agaric basidiomycete Agrocybe aegerita oxidizes aryl alcohols and aldehydes. Appl. Environ. Microbiol. 2004, 70, 4575-4581.

[2] Ullrich, R., Hofrichter, M., Enzymatic hydroxylation of aromatic compounds. Cell. Mol. Life Sci. 2007, 64, 271-293.

[3] Ullrich, R., Hofrichter, M., The haloperoxidase of the agaric fungus Agrocybe aegerita hydroxylates toluene and naphthalene. FEBS Lett. 2005, 579, 6247-6250. [4] Kinne, M., Ullrich, R., Hammel, K. E., Hofrichter, M., Regioselective preparation of (R)-2-(4-Hydroxyphenoxy)propionic acid with a fungal peroxygenase. Tetrahedron Lett. 2008, 49, 5950-5953.

[5] Kluge, M., Ullrich, R., Dolge, C., Scheibner, K. et al., Hydroxylation of naphthalene by aromatic peroxygenase from Agrocybe aegerita proceeds via oxygen transfer from $\mathrm{H}_{2} \mathrm{O}_{2}$ and intermediary epoxidation. Appl. Microbiol. Biotechnol. 2008, 81, 1071-1076.

[6] Ullrich, R., Dolge, C., Kluge, M., Hofrichter, M., Pyridine as novel substrate for regioselective oxygenation with aromatic peroxygenase from Agrocybe aegerita. FEBS J. 2008, 582, 4100-4106.

[7] Pecyna, M., Ullrich, R., Bittner, B., Clemens, A. et al., Molecular characterization of aromatic peroxygenase from Agrocybe aegerita. Appl. Microbiol. Biotechnol. 2009, [Epub ahead of print].

[8] Ollikka, P., Leppanen, V. M., Anttila, T., Suominen, I., Purification of major lignin peroxidase isoenzymes from Phanerochaete chrysosporium by chromatofocusing. Protein Expr. Purif. 1995, 6, 337-342.

[9] Michniewicz, A., Ullrich, R., Ledakowicz, S., Hofrichter, M., The white-rot fungus Cerrena unicolor strain 137 produces two laccase isoforms with different physico-chemical and catalytic properties. Appl. Microbiol. Biotechnol. 2006, 69, $682-688$. 
[10] Anh, D. H., Ullrich, R., Benndorf, D., Svatos, A. et al., The coprophilous mushroom Coprinus radians secretes a haloperoxidase that catalyzes aromatic peroxygenation. Appl. Environ. Microbiol. 2007, 73, 5477-5485.

[11] Podgornik, H., Podgornik, A., Separation of manganese peroxidase isoenzymes on strong anion-exchange monolithic column using $\mathrm{pH}$-salt gradient. J. Chromatogr. B Analyt. Technol. Biomed. Life Sci. 2004, 799, 343-347.

[12] Kaltenbrunner, O., Tauer, C., Brunner, J., Jungbauer, A., Isoprotein analysis by ion-exchange chromatography using a linear $\mathrm{pH}$ gradient combined with a salt gradient. J. Chromatogr. A 1993, 639, 41-49.

[13] Su, C., Oliw, E. H., Purification and characterization of linoleate 8dioxygenase from the fungus Gaeumannomyces graminis as a novel hemoprotein. J. Biol. Chem. 1996, 271, 14112-14118.

[14] Kang, X., Frey, D. D., Chromatofocusing of peptides and proteins using linear pH gradients formed on strong ion-exchange adsorbents. Biotechnol. Bioeng. 2004, 87, 376-387.

[15] Gagnon, P., Chromatofocusing: Does it really stack up as a process tool? Validated Biosystems Quarterly Resource Guide to Downstream Processing. http://www. validated.com/revalbio/pdffiles/chrfocus.pdf 1999.

[16] Ayala, A., Parrado, J., Machado, A., Use of Rotofor preparative isoelectrofocusing cell in protein purification procedure. Appl. Biochem. Biotechnol. 1998, 69, 11-16.

[17] Moralés, M., Pedreño, M., A., Muñoz, R., Ros Barceló, A., Calderón, A. A., Anomalous behaviour of acidic grapevine peroxidase isoenzymes during preparative isoelectric focusing. Phytochem. Anal. 1994, 5, 1-3.

[18] Schneegaß, I., Hofrichter, M., Scheibner, K., Fritsche, W., Purification of the main manganese peroxidase isoenzyme MnP2 from the white-rot fungus Nematoloma frowardii b19. Appl. Microbiol. Biotechnol. 1997, 48, 602-605. 
[19] Egen, N. B., Bliss, M., Mayersohn, M., Owens, S. M. et al., Isolation of monoclonal antibodies to phencyclidine from ascites fluid by preparative isoelectric focusing in the Rotofor. Anal. Biochem. 1988, 172, 488-494.

[20] Righetti, P. G., Bossi, A., Wenisch, E., Orsini, G., Protein purification in multicompartment electrolyzers with isoelectric membranes. J. Chromatogr. B Biomed. Sci. Appl. 1997, 699, 105-115.

[21] Tan, N. S., Ho, B., Ding, J. L., High-affinity LPS binding domain(s) in recombinant factor $\mathrm{C}$ of a horseshoe crab neutralizes LPS-induced lethality. FASEB J. 2000, 14, 859-870.

[22] Righetti, P. G., Gelfi, C., Perego, M., Stoyanov, A. V. et al., Capillary zone electrophoresis of oligonucleotides and peptides in isoelectric buffers: Theory and methodology. Electrophoresis 1997, 18, 2145-2153.

[23] Esteve-Romero, J. S., Bossi, A., Righetti, P. G., Purification of thermamylase in multicompartment electrolyzers with isoelectric membranes: The problem of protein solubility. Electrophoresis 1996, 17, 1242-1247.

[24] Heinzkill, M., Bech, L., Halkier, T., Schneider, P. et al., Characterization of laccases and peroxidases from wood-rotting fungi (family Coprinaceae). Appl. Environ. Microbiol. 1998, 64, 1601-1606.

[25] Taie, H. A. A., El-Mergawi, R., Radwan, S., Isoflavonoids, phenolic acids profiles and antioxidant activity of soybean seeds as affected by organic and bioorganic fertilization. American-Eurasion J. Agric. Environ. Sci. 2008, 4, 207-213. [26] Ramage, P., Mathis, B., Fendrich, G., Benoit, R., Purification of phosphorylated protein kinases using MonoBeads ion exchange media. Discov. Matt. 2007, 5, 22-23.

[27] Fukushima, Y., Kirk, T. K., Laccase component of the Ceriporiopsis subvermispora lignin-degrading system. Appl. Environ. Microbiol. 1995, 61, 872876. 
[28] Hilden, K. S., Bortfeldt, R., Hofrichter, M., Hatakka, A. et al., Molecular characterization of the basidiomycete isolate Nematoloma frowardii b19 and its manganese peroxidase places the fungus in the corticioid genus Phlebia. Microbiology 2008, 154, 2371-2379.

[29] Glukhovskiy, P., Landers, T. A., Vigh, G., Preparative-scale isoelectric focusing separation of enantiomers using a multicompartment electrolyzer with isoelectric membranes. Electrophoresis 2000, 21, 762-766.

[30] Balland, A., Mahan-Boyce, J. A., Krasts, D. A., Daniels, M. et al., Characterization of the isoforms of PIXY321, a granulocyte-macrophage-colony stimulating factor-interleukin-3 fusion protein, separated by preparative isoelectric focusing on immobilized pH gradients. J. Chromatogr. A 1999, 846, 143-156.

[31] Scott, C. A., Garcia, K. C., Stura, E. A., Peterson, P. A. et al., Engineering protein for X-ray crystallography: The murine major histocompatibility complex class II molecule I-Ad. Protein Sci. 1998, 7, 413-418.

[32] Delincée, H., Radola, B. J., Anomalous behaviour of horseradish peroxidase in isoelectric focusing, in: Radola, B. J., Graesslin, D. (Eds.) Electrofocusing and Isotachophoresis, Walter de Gruyter, Berlin 1977, pp 181-188.

[33] Tlecuitl-Beristain, S., Sanchez, C., Loera, O., Robson, G. D. et al., Laccases of Pleurotus ostreatus observed at different phases of its growth in submerged fermentation: Production of a novel laccase isoform. Mycol. Res. 2008, 112, 10801084.

[34] Ramirez-Coronel, M. A., Viniegra-Gonzalez, G., Darvill, A., Augur, C., A novel tannase from Aspergillus niger with beta-glucosidase activity. Microbiology 2003, 149, 2941-2946.

[35] Yamasaki, Y., Konno, H., Noda, K., Polyphenol oxidase from wheat bran is a serpin. Acta Biochim. Pol. 2008, 55, 325-328.

[36] Sae, A. S. W., Cunningham, B. A., Isolation and properties of chloroperoxidase isoenzymes. Phytochemistry 1979, 18, 1785-1787. 
[37] Kenigsberg, P., Fang, G. H., Hager, L. P., Post-translational modifications of chloroperoxidase from Caldariomyces fumago. Arch. Biochem. Biophys. 1987, 254, 409-415.

Figure 1. (A) FPLC elution profile of the first purification step (pre-purification) of AaP using the strong cation exchanger SP Sepharose FF. The pooled AaP fraction obtained was the starting material for all further separation studies. (B) Analytical IEF gel of the pre-purified AaP proteins (2), protein marker (1). (C) Partial separation of AaP proteins on the strong cation exchanger Mono S, and (D) on the strong anion exchanger Mono Q. Solid line, absorbance at $420 \mathrm{~nm}$ (heme-thiolate of AaP); black circles, AaP activity assayed with veratryl alcohol at $\mathrm{pH}$ 7.0; dashed lines, $\mathrm{NaCl}$ gradient.

Figure 2. Preparative IEF of AaP using a Rotofor unit. (A) Gray bars, AaP fractions recovered from the focusing cell and assayed with veratryl alcohol $(\mathrm{pH} 7.0)$; black circles, $\mathrm{pH}$ gradient. Fractions with the highest AaP activity are highlighted in gray (fraction 5-12) and were analyzed in an IEF gel (B). M, protein marker.

Figure 3. Separation of different AaP forms by chromatofocusing. (A) Elution profile recorded after chromatofocusing on the mixed anion exchanger Mono P; separated AaP forms are highlighted in gray. Solid line, absorbance at $420 \mathrm{~nm}$; black circles, AaP activity assayed with veratryl alcohol ( $\mathrm{pH} 7.0)$; thin dashed line, concentration buffer B (\%); thick dashed line, actual pH gradient. (B) Separated AaP forms visualized in an IEF gel; AaP I (p/6.1), AaP II (p/5.6), AaP III (p/5.2). 
Table 1. Purification of the three main isoforms of AaP (I-III) by FPLC

\begin{tabular}{lccccc}
\hline Purification step & $\begin{array}{c}\text { Protein } \\
(\mathrm{mg})\end{array}$ & $\begin{array}{c}\text { Total } \\
\text { activity }(\mathrm{U})\end{array}$ & $\begin{array}{c}\text { Specific activity } \\
(\mathrm{U} / \mathrm{mg})\end{array}$ & $\begin{array}{c}\text { Yield } \\
(\%)\end{array}$ & $\begin{array}{c}\text { Purification } \\
(\mathrm{x} \text {-fold })\end{array}$ \\
\hline Culture liquid & 60 & 141 & 2 & 100 & \\
Ultrafiltration & 55 & 140 & 2 & 99 & 1 \\
SP Sepharose & 35 & 135 & 4 & 96 & 2 \\
Mono P, AaP I & 0.56 & 43 & 77 & 30 & 33 \\
Mono P, AaP II & 0.35 & 33 & 94 & 23 & 40 \\
Mono P, AaP III & 0.36 & 37 & 103 & 26 & 44 \\
\hline
\end{tabular}


Table 2. Oxidation of toluene and naphthalene by the three major AaP forms obtained after Mono P separation

\begin{tabular}{llccc}
\hline \multirow{2}{*}{ Substrate } & Products & \multicolumn{3}{c}{ \% $^{\mathrm{a})}$ of products formed by } \\
& Benzyl alcohol & 22.5 & 22.1 & 22.0 \\
& Benzaldehyde & 25.6 & 25.9 & 26.8 \\
& Benzoic acid & 16.1 & 18.1 & 18.2 \\
\cline { 2 - 5 } Toluene & o-Cresol & 1.4 & 1.3 & 1.1 \\
& p-Cresol & 2.4 & 2.0 & 1.8 \\
& Methylhydroquinone & 32.0 & 30.6 & 30.0 \\
\cline { 2 - 5 } & Total & 100 & 100 & 99.9 \\
\cline { 2 - 5 } & 1-Naphthol & 94.0 & 93.5 & 94.5 \\
& 2-Naphthol & 6.0 & 7.0 & 6.0 \\
\cline { 2 - 5 } Naphthalene & Total & 102.4 & 99.8 & 99.4 \\
\hline
\end{tabular}

a) Percentages are given as mean values of three different measurements with SD $<5 \%$. 

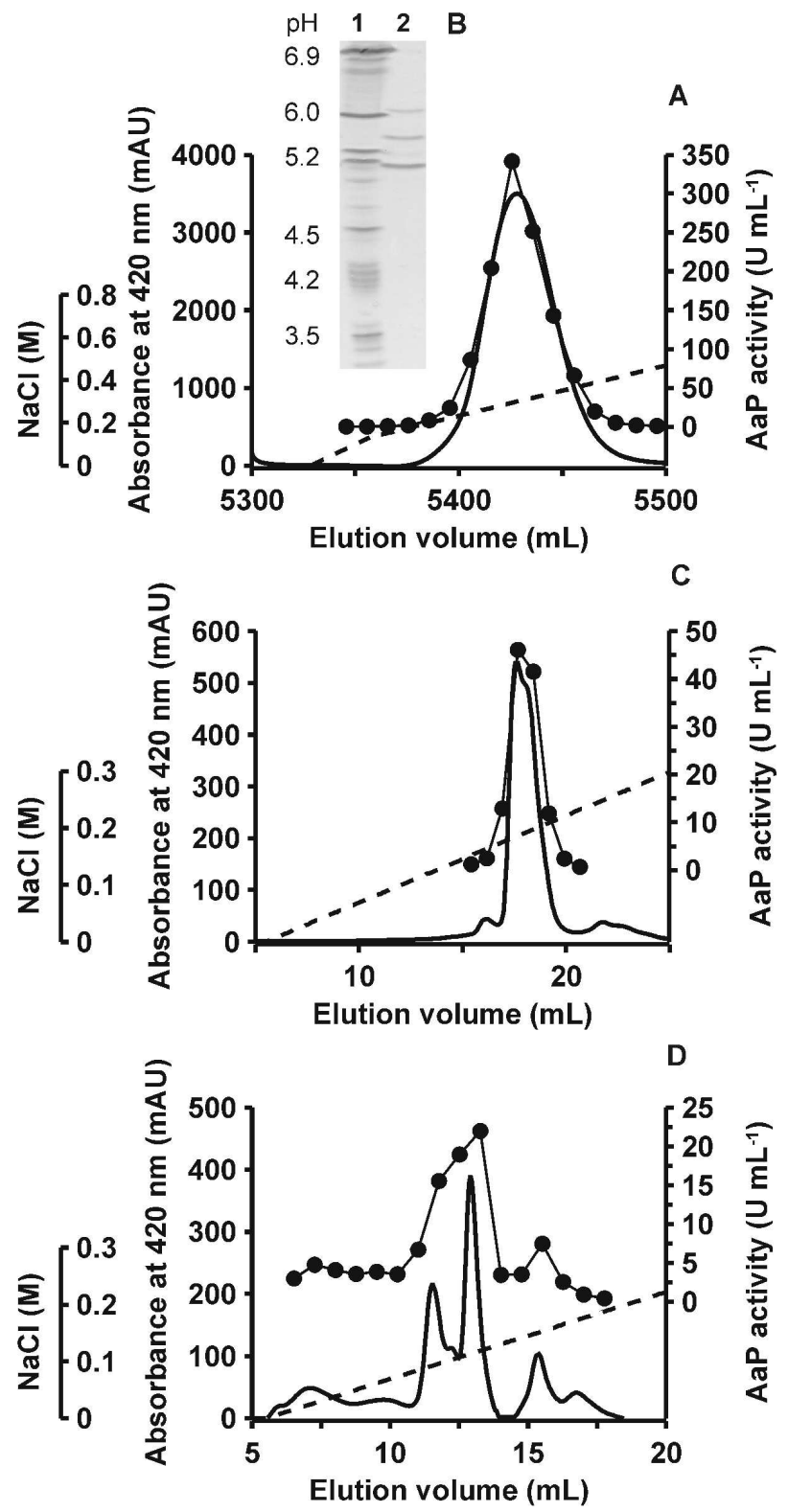

(A) FPLC elution profile of the first purification step (pre-purification) of Agrocybe aegerita peroxygenase (AaP) using the strong cation exchanger SP Sepharose FF. The pooled AaP fraction obtained was the starting material for all further separation studies. (B) Analytical IEF gel of the pre-purified AaP proteins (2), protein marker (1). (C) Partial separation of AaP proteins on the strong cation exchanger Mono S and (D) on the strong anion exchanger Mono Q. Solid line absorbance at $420 \mathrm{~nm}$ (heme-thiolate of AaP), black circles - AaP activity assayed with veratryl alcohol at $\mathrm{pH} 7.0$, dashed lines $-\mathrm{NaCl}$ gradient. 

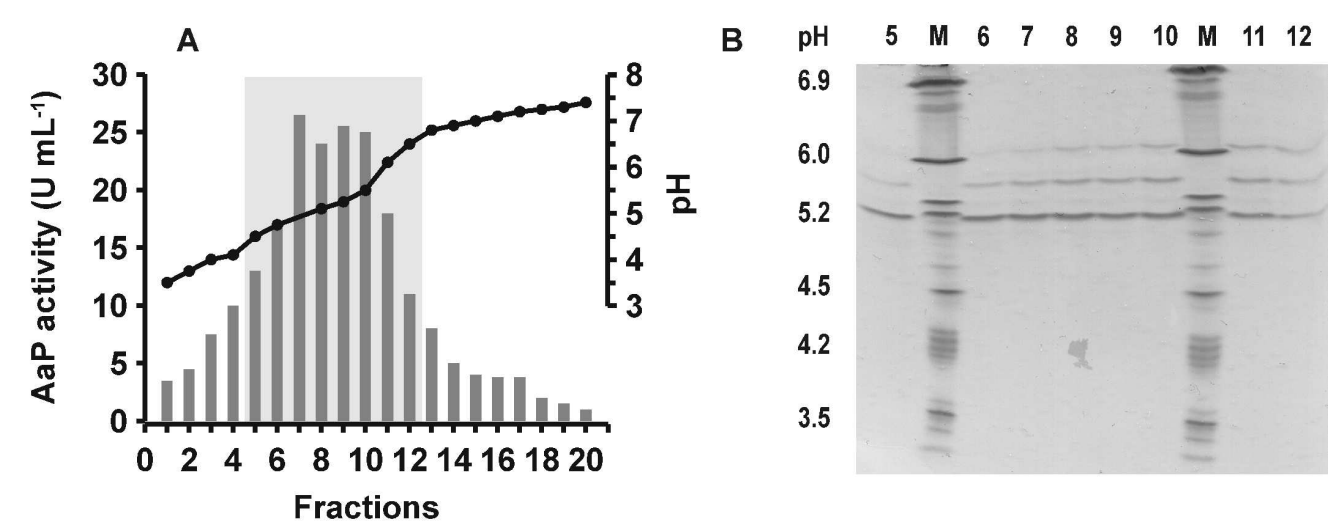

Preparative isoelectric focusing of $A$. aegerita peroxygenase using a Rotofor unit. (A) Grey bars AaP fractions recovered from the focusing cell and assayed with veratryl alcohol ( $\mathrm{pH} 7.0)$, black circles - pH gradient. Fractions with the highest AaP activity are highlighted in grey (fraction 5-12) and were analyzed in an IEF gel (B), protein marker (M). 


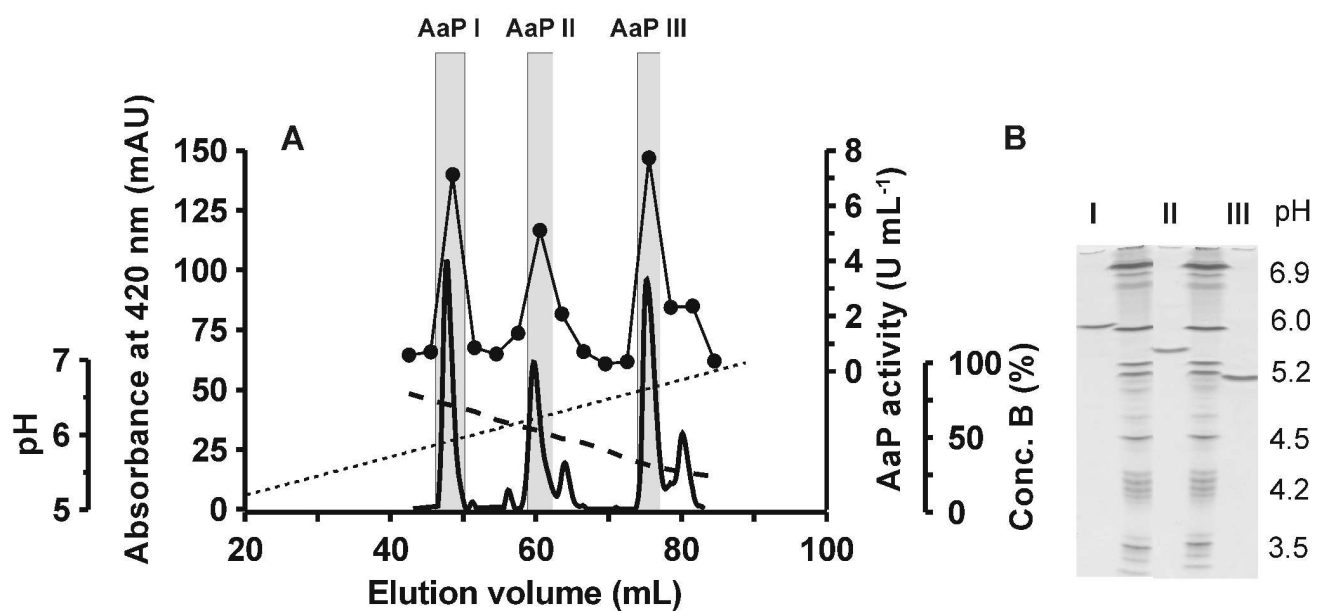

Separation of different AaP forms by chromatofocusing. (A) Elution profile recorded after chromatofocusing on the mixed anion exchanger Mono P, separated AaP forms are highlighted in grey. Solid line - absorbance at $420 \mathrm{~nm}$, black circles - AaP activity assayed with veratryl alcohol $(\mathrm{pH} 7.0)$, thin dashed line - concentration buffer B (\%), thick dashed line - actual pH gradient; (B) separated AaP forms visualized in an IEF gel - AaP I (pI 6.1), AaP II (pI 5.6), AaP III (5.2). 